\title{
Pengaruh Komunikasi dan Tanggung Jawab terhadap Kinerja Pegawai pada Badan Pusat Statistik Provinsi Sumatera Barat
}

\author{
Rifmanesi, Elfianto Yusuf, Budi Yanti
}

Fakultas Ekonomi, Universitas Tamansiswa Padang, Jl. Tamansiswa No. 9 Padang

\section{INFORMASI ARTIKEL}

\section{Sejarah Artikel:}

Diterima Redaksi: Desember 2018

Revisi Akhir: Januari 2019

Diterbitkan Online: Januari 2019

\section{KATA KUNCI}

Komunikasi, Tanggung Jawab dan Kinerja

KORESPONDENSI

Telepon:

E-mail: budiyantibudi04@gmail.com

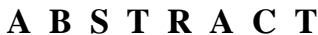

Tujuan dari penelitian ini adalah untuk mengetahui dan menganalisis pengaruh komunikasi dan tanggung jawab terhadap kinerja pegawai pada Badan Pusat Statistik Provinsi Sumatera Barat. Populasi dalam penelitian ini adalah seluruh pegawai sebanyak 76 orang pegawai BPS Provinsi Sumatera Barat. Hasil analisis regresi linear berganda diperolah persamaan $\mathrm{Y}=0,641+0,697 \mathrm{X}_{1}+1,230 \mathrm{X}_{2}+\mathrm{e}$. Hal ini ditunjukkan dengan hasil uji t untuk komunikasi dan tanggung jawab secara parsial berpengaruh positif dan signifikan terhadap kinerja pegawai pada Badan Pusat Statistik Provinsi Sumatera. Dan hasil uji f diperoleh bahwa komunikasi dan tanggung jawab secara bersamasama berpengaruh terhadap kinerja pegawai pada Badan Pusat Statistik Provinsi Sumatera. Nilai koefisien determinasi terdapat pada nilai Adjusted R Square sebesar 57,7\%.

\section{PENDAHULUAN}

Komunikasi menjadi bagian terpenting, namun rasa tanggung jawab seorang pegawai terhadap kewajiban yang telah di amanahkan juga menjadi hal utama. Seorang pegawai mempunyai hak dan kewajiban yang harus dilaksanakan dan keduanya merupakan mata rantai saling berkaitan. Seorang pegawai mempunyai hak untuk memperoleh penghasilan berupa gaji dan harus memenuhi kewajiban pekerjaan sesuai dengan tupoksi dengan penuh tanggung jawab.

Tanggung jawab adalah keharusan untuk melakukan semua kewajiban tugas-tugas yang dibebankan kepadanya sebagai akibat dari wewenang yang diterima atau dimilikinya. Tanggung jawab timbul karena adanya hubungan antara atasan dan bawahan, dimana atasan mendelegasikan sebagai wewenang 
pekerjaannya kepada bawahan untuk dikerjakan. Tanggung jawab mengalir dari bawah ke atas, jadi merupakan arus balik dari perintah-perintah itu.

Sejalan dengan penjelasan di atas, Badan Pusat Statistik (selanjutnya disebut "BPS") yang merupakan Lembaga Pemerintah Nonkementerian yang bertanggungjawab langsung kepada Presiden yang mempunyai fungsi pokok sebagai penyedia data statistik dasar, baik untuk pemerintah maupun untuk masyarakat umum, secara nasional maupun regional.

Untuk itu, BPS harus mampu memberikan pelayanan terbaik untuk pemerintah, peneliti, dan masyarakat yang membutuhkan data. Data yang dibutuhkan oleh si pengguna data tersebut telah disajikan dalam bentuk publikasi maupun informasi lainnya. Dimana data tersebut melewati proses yang panjang mulai dari perencanaan, perancangan, pengumpulan, pengolahan hingga penyajian. Demi terwujudnya data yang berkualitas, BPS membutuhkan SDM yang berkualitas yang memiliki keterampilan, keahlian, kecerdasan, integritas tinggi, dan kecakapan komunikasi.

Sesuai dengan standart operasional prosedur, BPS menentukan jadwal untuk setiap pelaksanaan kegiatan yang dimulai dari persiapan, pelaksanaan hingga evaluasi. Pada tahap pelaksanaan ada beberapa tahap kegiatan yang harus dilaksanakan berurutan, yaitu pelatihan, pencacahan, pemeriksaan, editing- coding, pengolahan, tabulasi, dan penyajian. Pada tahap pelaksanaan inilah penulis menemukan adanya pekerjaan yang terlewat dari jadwal pelaksanaan. Masih ada pegawai belum tepat waktu untuk menyelesaikan beban kerja yang menjadi kewajibannya.

Selain itu, permasalahan yang terjadi baik dilapangan maupun di dalam kantor tidak terkomunikasi secara detail dan cepat. Seperti adanya responden pencacahan yang belum ditemukan, artinya keberadaan responden yang akan diwawancarai tersebut tidak diketahui sehingga pencacahan belum dapat dilakukan. Kondisi lain responden tersebut telah tutup, artinya responden tersebut sudah tidak melakukan kegiatan sesuai dengan target pencacahan lagi. Hal seperti ini akan berdampak pada pelaksanaan kegiatan tersebut jika tidak disampaikan secara cepat. Jika informasi cepat diterima, tentu ada langkahlangkah yang harus diambil untuk memberikan solusi permasalahan. Namun sebaliknya, jika informasi tersebut tidak diinfomasikan tentu akan berdampak ke pekerjaan yang tidak berjalan lancar. Hal ini juga dapat menimbulkan berbagai asumsi-asumsi dan berakibat pada kinerja individu itu sendiri.

Pada BPS Provinsi Sumatera Barat hasil kerja pegawai dinilai setiap bulan oleh pimpinan dimana setiap pegawai setiap bulannya diharuskan membuat Capaian Kinerja Pegawai Target (CKP-T) dan Capaian Kinerja 
Pegawai Realisasi (CKP-R). Dengan adanya Capaian Kinerja Pegawai Target/Realisasi (CKP-T/R) semua pegawai diberi target, sehingga jika tidak dapat merealisasikan target yang sudah ditetapkan, berpengaruh pada tunjangan kinerja yang akan diperoleh pegawai tersebut. Berdasarkan uraian di atas, penulis tertarik untuk melakukan penelitian dengan mengangkat judul "Pengaruh Komunikasi dan Tanggung Jawab Terhadap Kinerja Pegawai Pada BPS Provinsi Sumatera Barat".

\section{Rumusan Masalah}

Berdasarkan uraian latar belakang yang telah dikemukakan, maka rumusan masalah dalam penulisan ini, adalah :

1. Apakah komunikasi berpengaruh terhadap kinerja pegawai di BPS Provinsi Sumatera Barat?

2. Apakah tanggung jawab berpengaruh terhadap kinerja pegawai di BPS Provinsi Sumatera Barat?

3. Apakah komunikasi dan tanggung jawab berpengaruh secara bersamaan terhadap kinerja pegawai pada BPS Provinsi Sumatera Barat?

\section{Tujuan Penelitian}

Berdasarkan perumusan masalah diatas, maka tujuan dari penelitian ini adalah:
1. Mengetahui pengaruh komunikasi terhadap kinerja pegawai di BPS Provinsi Sumatera Barat.

2. Mengetahui pengaruh tanggung jawab terhadap kinerja pegawai di BPS Provinsi Sumatera Barat.

3. Mengetahui pengaruh komunikasi dan tanggung jawab secara bersamaan terhadap kinerja pegawai di BPS Provinsi Sumatera Barat.

\section{LANDASAN TEORI}

\section{Komunikasi}

Menurut Widjaja (2010:5) komunikasi adalah proses penyampaian informasi, opini, ide, konsepsi, pengetahuan, perasaan, sikap, perbuatan dan sebagainya kepada sesamanya secara timbal balik, baik sebagai penyampaian maupun penerima komunikasi. Komunikasi menurut Muhammad (2009:2) adalah proses individu mengirim stimulus yang biasanya dalam bentuk verbal untuk mengubah tingkah laku orang lain. Stimulus dapat disebut sebagai pesan yang biasanya dalam bentuk verbal, dimana proses penyampaian yang dilakukan melalui saluran komunikasi, dan terjadi perubahan atau respons terhadap pesan yang disampaikan.

Menurut Setiadi (2008), komunikasi adalah proses dimana seorang individu (komunikator) mengoperkan perangsang (biasanya lambang-lambang bahasa) untuk 
merubah tingkah laku individu-individu yang lain (komunikan). Selain itu menurut pendapat Effendy (2007:10) komunikasi adalah proses penyampaian pesan, pelayanan, pemahaman, profesionalisme tugas dan keramah-tamahan oleh komunikator (seseorang) kepada komunikan (orang lain) untuk memberitahu, mengubah sikap, pendapat atau perilaku baik secara lisan (langsung) ataupun tidak langsung melalui media (email dan website) yang dapat menimbulkan efek tertentu.

\section{Tanggung Jawab}

Tanggung jawab merupakan nilai moral penting dalam kehidupan bermasyarakat. Tanggung jawab juga merupakan perwujudan kesadaran akan kewajiban. Menurut Musmulyadi (2016), tanggung jawab adalah keyakinan dan kesanggupan seseorang untuk melaksanakan tugas dan kewajiban yang dibebankan sesuai kemampuan.

Sukiat (1993) mendefinisikan tanggung jawab adalah keputusan untuk menerima tugas kewajiban, kepada sesuatu diluar dirinya ataupun kepada dirinya sendiri dan memiliki kebebasan untuk menentukan sikap dan pilihannya serta menanggung konsekuensinya dari penentuan sikap dan pilihannya itu. Timpe(2000), mengungkapkan bahwa tanggung jawab adalah satu faktor terpenting seorang individu dalam mencapai produktivitas tinggi pada organisasi yang berdasarkan teknologi dan kecakapan manajemen yang dimiliki dalam melaksanakan tugas dan kewajiban.

\section{Kinerja}

Kinerja merupakan gambaran mengenai tingkat pencapaian pelaksanaan suatu program kegiatan atau kebijakan dalam mewujudkan sasaran, tujuan, visi dan misi organisasi yang dituangkan melalui perencanaan strategis suatu organisasi (Moeheriono, 2012:95).

Kinerja adalah kondisi dari sebuah kelompok di mana ada tujuan yang jelas dan tetap yang dirasakan menjadi penting dan terpadu dengan tujuan individu (Panggabean,2004). Menurut Nitisemito (2003), kinerja adalah melakukan pekerjaan secara lebih giat, sehingga dengan demikian pekerjaan akan diharapkan lebih cepat dan lebih baik.

Menurut Hasibuan (2013:34), bahwa kinerja adalah hasil kerja yang dicapai seseorang dalam melaksanakan tugas-tugas yang dibebankan kepadanya yang didasarkan atas kecakapan, pengalaman, dan kesungguhan serta waktu. Menurut Nawawi (2012), kinerja adalah hasil kerja seseorang secara kualitas dan kuantitas yang dicapai oleh seorang pegawai dalam melaksanakan tugasnya sesuai dengan tanggung jawab yang diberikan kepadanya.

\section{Kerangka Konseptual}


Kerangka konseptual dalam penelitian ini adalah sebagai berikut:

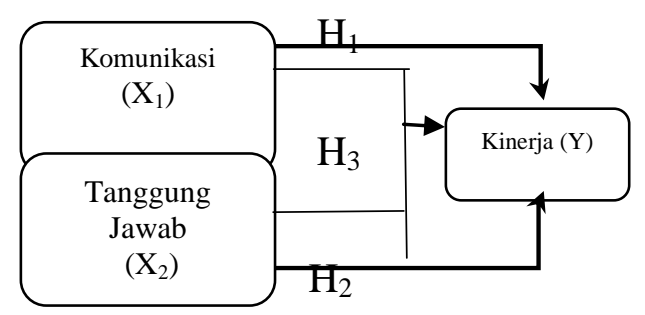

\section{Hipotesis Penelitian}

Berdasarkan kajian teori yang dikemukakan diatas, maka hipotesis dalam penelitian ini adalah sebagai berikut :

$\mathrm{H}_{1}$ : Diduga komunikasi berpengaruh signifikan terhadap kinerja pegawai di BPS Propinsi Sumatera Barat.

$\mathrm{H}_{2}$ : Diduga rasa tanggung jawab berpengaruh secara signifikan terhadap kinerja pegawai di BPS Propinsi Sumatera Barat.

$\mathrm{H}_{3}$ : Diduga komunikasi dan tanggung jawab secara bersamaan berpengaruh secara signifikan terhadap kinerja pegawai di BPS Provinsi Sumatera Barat.

\section{METODOLOGI PENELITIAN}

Metodologi penelitian yang digunakan dalam penelitian ini adalah penelitian kuantitatif. Adapun pendekatan yang digunakan adalah deskriptif kuantitatif.

\section{Populasi}

Populasi adalah seperangkat analisis yang lengkap yang sedang diteliti (Sarwono, 2009:319). Populasi dalam penelitian ini adalah pegawai Badan Pusat Statistik (BPS) Provinsi Sumatera Barat yang berjumlah 76 orang.

\section{Sampel}

Teknik pengambilan sampel dalam penelitian ini menggunakan teknik total sampling, yaitu semua populasi dijadikan sampel, sehingga sampel dalam penelitian ini berjumlah 76 orang pegawai.

\section{Teknik Analisis Data}

\section{Analisis Deskriptif}

Setiap jawaban dan pernyataan angket penelitian dilakukan dengan memberikan bobot atau skor yang disusun secara bertingkat berdasarkan skala likert. Skala likert merupakan pengukuran yang di gunakan dengan mengukur sikap, pendapat dan persepsi seseorang atau sekelompok orang mengenai fenomena sosial (Sugiyono, 2007:132).

\section{Uji Validitas}

Validitas suatu butir pernyataan dapat dilihat pada hasil Statistical Program for Social Sciences (SPSS) pada tabel dengan judul Pearson Correlation. Menilai kevalidan masing-masing butir pertanyaan dapat dilihat dari nilai Pearson Correlation yang merupakan 
nilai r-hitung dari setiap masing-masing butir pertanyaan. Suatu butir pernyataan dikatakan valid jika nilai $\mathrm{r}_{\text {hitung }}>\mathrm{r}_{\text {tabel. }}$.

\section{Uji Reliabilitas}

Uji reliabilitas dilakukan pada masingmasing variabel sehingga dapat variabel mana yang tidak reliabel. Reliabilitas suatu variabel dikatakan baik jika memiliki nilai Cronbach's Alpha lebih besar dari 0,6.

\section{Analisis Regresi Linear Berganda}

Analisis ini digunakan untuk mengetahui seberapa besar pengaruh variabel bebas yaitu: Komunikasi $\left(\mathrm{X}_{1}\right)$, Tanggung Jawab $\left(\mathrm{X}_{2}\right)$ terhadap variabel terikatnya yaitu Kinerja (Y). Maka digunakan rumus sebagai berikut (Gujarati, 2006):

$$
\mathbf{Y}=\mathbf{a}+\mathbf{b}_{1} \mathbf{X}_{1}+\mathbf{b}_{2} \mathbf{X}_{2}+\mathbf{e}
$$

dimana: $\mathrm{Y}=$ Kinerja.

$$
\begin{aligned}
& \mathrm{a}=\text { Konstanta. } \\
& \mathrm{b}=\text { Koefisien regresi. } \\
& \mathrm{X}_{1}=\text { Komunikasi } \\
& \mathrm{X}_{2}=\text { Tanggung Jawab. } \\
& \mathrm{e}=\text { Standart error } .
\end{aligned}
$$

\section{Uji t}

Digunakan untuk mengetahui pengaruh dari masing-masing variabel, baik variabel bebas terhadap variabel terikat tersebut yang signifikan secara statistik. Menggunakan uji masing-masing koefisien regresi variabel bebas apakah mempunyai pengaruh yang bermakna atau tidak terhadap variabel terikat (Sugiyono, 2014).

\section{Uji F}

Untuk menguji hipotesis digunakan uji nilai $\mathrm{F}$ untuk membuktikan tingkat keberartian variabel bebas terhadap variabel terikat. Ketentuan uji signifikan ini bila $F_{\text {hitung }}>F_{\text {tabel }}$ maka koefisien regresi sederhana yang diuji adalah signifikan dan sebaliknya bila $\mathrm{F}_{\text {hitung }}<\mathrm{F}_{\text {tabel }}$ maka koefisien regresi sederhana yang diuji tidak signifikan.

\section{Koefisien Determinasi $\left(\mathbf{R}^{2}\right)$}

Setelah koefisien korelasi diketahui, maka selanjutnya menghitung koefisien determinasi, yaitu untuk mengetahui seberapa besar pengaruh variabel $\mathrm{X}_{1}$ (Komunikasi), $\mathrm{X}_{2}$ (Tanggung Jawab) terhadap variabel $\mathrm{Y}$ (Kinerja).

\section{HASIL PENELITIAN}

\section{Hasil Analisis Regresi Linear Berganda}

Berdasarkan analisis data dengan menggunakan program SPSS 20 for windows, maka diperoleh hasil persamaan regresi sebagai berikut:

$$
\mathrm{Y}=0,641+0,697 \mathrm{X}_{1}+1,230 \mathrm{X}_{2}+\mathrm{e}
$$




\section{Tabel 1. Hasil Analisis Regresi Linear Berganda}

\begin{tabular}{|c|c|c|c|c|c|}
\hline \multicolumn{6}{|c|}{ Coefficients $^{\mathrm{a}}$} \\
\hline \multirow[t]{2}{*}{ Model } & \multicolumn{2}{|c|}{ Unstandardized Coefficients } & \multirow{2}{*}{$\begin{array}{c}\text { Standardized } \\
\text { Coefficients }\end{array}$} & \multirow[t]{2}{*}{$\mathrm{t}$} & \multirow[t]{2}{*}{ Sig. } \\
\hline & $\bar{B}$ & Std. Error & & & \\
\hline (Constant) & .641 & 7.903 & & .081 & .936 \\
\hline 1 Komunikasi & .697 & .196 & .310 & 3.547 & .001 \\
\hline Tanggung Jawab & 1.230 & .192 & .561 & 6.416 & .000 \\
\hline
\end{tabular}

Sumber: Data primer yang diolah (2018)

1. Persamaan regresi diatas memperlihatkan hubungan antara variabel independen dengan variabel dependen secara parsial, dari persamaan tersebut dapat diambil kesimpulan bahwa : Nilai konstanta adalah $=0,641$, artinya jika tidak ada terjadi perubahan variabel komunikasi dan tanggung jawab (nilai $\mathrm{X}_{1}$ dan $\mathrm{X}_{2}$ adalah 0) maka kinerja pegawai BPS Provinsi Sumatera Barat tetap sebesar 0,641 satuan.

2. Nilai koefisien regresi komunikasi adalah $=$ 0,697, artinya jika variabel komunikasi $\left(\mathrm{X}_{1}\right)$ meningkat sebesar 1 (satuan) dengan asumsi variabel tanggung jawab $\left(\mathrm{X}_{2}\right)$ dan konstanta (a) adalah 0 (nol), maka kinerja pegawai BPS Provinsi Sumatera Barat meningkat sebesar 0,697 satuan.

3. Nilai koefisien regresi tanggung jawab adalah $=1,230$, artinya jika variabel tanggung jawab $\left(\mathrm{X}_{2}\right)$ meningkat sebesar 1 (satuan) dengan asumsi variabel komunikasi $\left(\mathrm{X}_{1}\right)$ dan konstanta (a) adalah 0 (nol), maka kinerja pegawai BPS Provinsi Sumatera Barat meningkat sebesar 1,230 satuan.

\section{Uji Hipotesis}

\section{Uji t}

Pada penelitian uji $\mathrm{t}$ ini dilakukan pada 76 responden dimana df $=n-k=76-3=73$ dengan taraf signifikan sebesar $5 \%$ maka $t_{\text {tabel }}$ adalah 1,666. Berdasarkan analisis data dengan menggunakan program SPSS 20 for windows, maka diperoleh disimpulkan :

1. Pengaruh Variabel Komunikasi Terhadap Kinerja $\left(\mathrm{H}_{1}\right)$

Berdasarkan tabel 4.13, diketahui bahwa nilai $t_{\text {hitung }}>\mathrm{t}_{\text {tabel }}$ yaitu 3,547>1,666 dan 
taraf signifikan $0,001<0,05$, maka Ho ditolak dan $\mathrm{H}_{1}$ diterima artinya komunikasi berpengaruh secara positif dan signifikan terhadap kinerja pegawai BPS Provinsi Sumatera Barat.

2. Pengaruh Variabel Tanggung Jawab Terhadap Kinerja $\left(\mathrm{H}_{2}\right)$

Berdasarkan tabel 4.13, diketahui bahwa nilai $t_{\text {hitung }}>t_{\text {tabel }}$ yaitu $6,416>1,666$ dan taraf signifikan $0,000<0,05$, maka Ho ditolak dan $\mathrm{H}_{2}$ diterimaartinya tanggung jawab berpengaruh secara positif dan signifikan terhadap kinerja pegawai BPS Provinsi Sumatera Barat.

3. Pengaruh Variabel Tanggung Jawab Terhadap Kinerja $\left(\mathrm{H}_{2}\right)$

Berdasarkan tabel 4.13, diketahui bahwa nilai $t_{\text {hitung }}>t_{\text {tabel }}$ yaitu $6,416>1,666$ dan taraf signifikan $0,000<0,05$, maka Ho ditolak dan $\mathrm{H}_{2}$ diterimaartinya tanggung jawab berpengaruh secara positif dan signifikan terhadap kinerja pegawai BPS Provinsi Sumatera Barat.

\section{Uji F}

Nugroho dalam Syafriadi (2016:45) mengemukakan uji simultan dengan F-test bertujuan untuk mengetahui pengaruh bersamasama variabel independen terhadap variabel dependen. Hasil F-test ini pada output SPSS versi 20 dapat dilihat pada tabel Anova. Hasil F-test menunjukan variabel independen secara bersama-sama berpengaruh terhadap variabel dependen jika $p$-value pada kolom Sig. <level of significant 0,05 atau $\mathrm{f}_{\text {hitung }}$ (pada kolom $\mathrm{F}$ ) > $\mathrm{f}_{\text {tabel }}$ yang dihitung dengan cara $\mathrm{df} 1=\mathrm{k}-1$ dan $\mathrm{df} 2=\mathrm{n}-\mathrm{k}, \mathrm{k}$ adalah jumlah variabel dependen dan independen.

Berdasarkan hasil pengujian pada tabel diatas dapat dilihat pada nilai $F_{\text {hitung }}$ sebesar 52,160 dengan nilai $\mathrm{F}_{\text {tabel }} d f_{1}=\mathrm{k}-1(3-1=2), d f_{2}$ $=\mathrm{n}-\mathrm{k}(76-3=73)$ adalah 3,12 sehingga nilai $F_{\text {hitung }}>F_{\text {tabel }}$ atau $52,0160>3,12$ dan taraf signifikan 0,000 $<0,05$ maka Ho ditolak dan $\mathrm{H}_{3}$ diterima, dapat disimpulkan bahwa variabel komunikasi $\left(\mathrm{X}_{1}\right)$ dan tanggung jawab $\left(\mathrm{X}_{2}\right)$ secara bersamaan berpengaruh signifikan terhadap kinerja pegawai pada BPS Provinsi Sumatera Barat.

\section{Uji Koefisien Determinasi}

Analisa koefisien determinasi dilakukan untuk mengetahui seberapa besar pengaruh atau variasi suatu variabel bisa dijelaskan oleh perubahan atau variasi pada variabel lain yang lain atau dengan kata lain seberapa besar kemampuan variabel bebas untuk berkontribusi terhadap variabel tetapnya dalam satuan presentase (Sugiyono, 2013:297).

\section{Pembahasan Hasil Penelitian}

Berdasarkan analisa data mengenai pengaruh variabel komunikasi $\left(\mathrm{X}_{1}\right)$ dan variabel tanggung jawab $\left(\mathrm{X}_{2}\right)$ serta secara individu dan 
secara bersamaan terhadap kinerja pegawai BPS Provinsi Sumatera Barat, maka pembahasan hasilnya adalah sebagai berikut:

\section{Pengaruh Variabel Komunikasi Terhadap Kinerja}

Dari hasil analisis uji hipotesa pada taraf kepercayaan $\alpha=5 \%$ terbukti bahwa variabel komunikasi $\left(\mathrm{X}_{1}\right)$ berpengaruh positif dan signifikan terhadap kinerja pegawai BPS Provinsi Sumatera Barat. Hal ini dibuktikan dengan nilai nilai $t_{\text {hitung }}>t_{\text {tabel }}(3,547>1,666)$ dan nilai signifikan $0,001<0,05$, maka Ho ditolak $\mathrm{H}_{1}$ diterima.

Berdasarkan Tabel dibawah, dapat diketahui bahwa nilai koefisien determinasi terdapat pada nilai Adjusted Rsquare sebesar 0,577 . Hal ini berarti kontribusi variabel bebas terhadap variabel terikat adalah sebesar 57,7\% sisanya $42,3 \%$ dijelaskan oleh variabel lain yang tidak dibahas dalam penelitian ini seperti faktor individu dan faktor lingkungan (Sutrisno, 2012:151).

Berdasarkan hasil penelitian yang dilakukan pada variabel komunikasi dapat disimpulkan bahwa kinerja pegawai BPS Provinsi Sumatera Barat dapat dipengaruhi oleh faktor pesan, pelayanan, pemahaman, profesionalisme, dan keramah-tamahan. Dari beberapa faktor tersebut yang paling dominan mempengaruhi kinerja pegawai BPS Provinsi Sumatera Barat adalah pegawai selalu menyampaikan hal yang benar dan mengakui kesalahan jika ditimbulkan dari dirinya.

Selain itu faktor yang juga cukup besar mempengaruhi adalah pegawai senang untuk berkomunikasi langsung dengan rekan kerja yang berwenang atas informasi yang diperolehnya sehingga pegawai mendapatkan informasi tepat dari sumbernya.

\section{Pengaruh Variabel Tanggung Jawab Terhadap Kinerja}

Dari hasil analisis uji hipotesa pada taraf kepercayaan $\alpha=5 \%$ terbukti bahwa variabel tanggung jawab $\left(\mathrm{X}_{2}\right)$ berpengaruh positif dan signifikan terhadap kinerja pegawai BPS Provinsi Sumatera Barat. Hal ini dibuktikan dengan nilai $t_{\text {hitung }}>t_{\text {tabel }}(6,416>1,666)$ dan nilai signifikan $0,00<0,05$, maka maka Ho ditolak $\mathrm{H}_{2}$ diterima.

Berdasarkan hasil penerlitian yang dilakukan pada variabel tanggung jawab dapat disimpulkan bahwa kinerja pegawai pada BPS Provinsi Sumatera Barat dipengaruhi faktor kualifikasi pekerjaan, motivasi tinggi, orientasi pekerjaan positif, dewasa, dan bergaul dengan efektif. Dari beberapa faktor tersebut yang paling dominan mempengaruhi kinerja adalah kualifikasi pekerjaan, dimana pegawai selalu memperhatikan setiap apa yang dikerjakan, menyelesaikan pekerjaan dengan sungguhsungguh. 
Pengaruh Variabel Komunikasi dan

\section{Tanggung Jawab Terhadap Kinerja}

Dari hasil uji F terbukti bahwa variabel komunikasi $\left(\mathrm{X}_{1}\right)$ dan tanggung jawab $\left(\mathrm{X}_{2}\right)$ secara bersama-sama mempunyai pengaruh yang positif dan signifikan terhadap kinerja pegawai pada BPS Provinsi Sumatera Barat. Hal ini dapat di buktikan dengan $F_{\text {hitung }}>F_{\text {tabel }}$ atau $52,160>3,12$ dan taraf signifikan 0,000<0,05, maka Ho ditolak dan $\mathrm{H}_{3}$ diterima sehingga dapat disimpulkan bahwa variabel komunikasi $\left(\mathrm{X}_{1}\right)$ dan tanggung jawab $\left(\mathrm{X}_{2}\right)$ secara bersama-sama berpengaruh signifikan terhadap kinerja pegawai BPS Provinsi Sumtera Baratsebesar $57,7 \%$ sisanya $42,3 \%$ dijelaskan oleh variabel lain seperti usia pegawai dan pengalaman kerja pegawai, selain itu dapat juga disebabkan oleh faktor lingkungan.

\section{KESIMPULAN}

Berdasarkan hasil penelitian yang telah dilakukan, maka dapat ditarik kesimpulan sebagai berikut:

1. Variabel komunikasi berpengaruh secara positif dan signifikan terhadap kinerja pegawai BPS Provinsi Sumatera Barat yang dapat dilihat berdasarkan nilai $t_{\text {hitung }}>t_{\text {tabel }}$ $(3,547>1,666)$ dan nilai signifikan sebesar $0,001<0,05$, maka Ho ditolak dan $\mathrm{H}_{1}$ diterima.

2. Variabel tanggung jawab berpengaruh positif dan signifikan terhadap kinerja pegawai BPS
Provinsi Sumatera Baratyang dilihat berdasarkan nilai $t_{\text {hitung }}>t_{\text {tabel }}$ $(6,416>1,666)$ dan nilai signifikan sebesar $0,000<0,05$ maka Ho ditolak dan $\mathrm{H}_{2}$ diterima.

3. Secara bersamaan terdapat pengaruh yang positif dan signifikan antara variable komunikasi dan tanggung jawab terhadap kinerja pegawai BPS Provinsi Sumatera Barat yang dapat dilihat berdasarkan nilai $F_{\text {hitung }}>F_{\text {tabel }} \quad(52,160>3,12)$ dan nilai signifikan sebesar $0,000<0,05$ maka Ho ditolak dan $\mathrm{H}_{3}$ diterima.Nilai koefisien determinasi terdapat pada nilai Adjusted Rsquare sebesar 0,577, sehingga dapat disimpulkan bahwa kontribusi variabel bebas dalam menjelaskan variabel terikat adalah sebesar $57,7 \%$, sisanya disebabkan oleh faktor lainnya seperti faktor usia dan pengalaman kerja serta faktor lingkungan.

\section{DAFTAR PUSTAKA}

Arikunto, Suharsimi. 2006. Prosedur Penelitian Suatu Pendekatan Praktek. PT. Rineka Cipta. Jakarta.

Arikunto, Suharsimi. 2010. Prosedur penelitian. Suatu Pendekatan Praktik. Edisi Revisi. Rineka Cipta. Jakarta.

Badan Pusat Statistik. 2018. Visi Misi BPS, http://www.bps.go.id/tentang-bps.html, diakses 17 Agustus 2018.

Burhanudin, Danang Sunyoto. 2015. Teori Perilaku Keorganisasian, Jilid Pertama. PT Buku Seru. Jakarta.

Effendy, Onong. U. 2007. Pengantar Ilmu Komunikasi. PT. Raja Grafindo. Jakarta. 
Febriyandi, Rensius. 2016. Pengaruh kepemimpinan dan komunikasi terhadap kinerja karyawan PT Kereta Api Indonesia (Persero) Sub. Divisi Regional III.2 Tanjung Karang Bandar Lampung. Skripsi

Ghozali, Imam. 2011. Aplikasi Analisis Multivariate Dengan Program SPSS. Universitas Diponegoro. Semarang.

Handoko, T. Hani. 2011. Manajemen Personalia dan Sumberdaya Manusia. Penerbit BPFE. Yogyakarta.

Hasibuan, M. S. 2013. Manajemen Sumber Daya Manusia. PT Bumi Aksara. Jakarta.

Kuncoro, Mudrajad. 2009. Metode Riset Untuk Bisnis dan Ekonomi. Erlangga. Jakarta.

Moeheriono. 2012. Pengukuran Kinerja Berbasis Kompetensi. Raja Grafindo Persada. Jakarta.

Mulyana, Deddy. 2007. Ilmu Komunikasi:

Suatu Pengantar. PT. Remaja Rosdakarya. Bandung.

Nitisemito, A.S. 2006. Manajemen Personalia. Graha Indonesia. Jakarta.

Nugroho, B. A. 2005. Strategi Jitu Memilih Metode Statistic Metode Penelitian Dengan SPSS. Penerbit Andi. Yogyakarta.
Panggabean, Mutiara, S. 2004. Manajemen Sumber Daya Manusia. Ghalia Indonesia. Jakarta.

Rismi, Somad. 2014. Manajemen Komunikasi. Alfabeta. Bandung.

Samsudin, Sadili. 2009. Manajemen Sumber Daya Manusia. CV Pustaka Setia. Bandung.

Setiadi, Nugroho J. 2008. Perilaku Konsumen : Konsep dan Implikasi Untuk Strategi dan Penelitian. Kencana. Jakarta.

Sopiah. 2008. Perilaku Organisasional. Penerbit Andi. Yogyakarta.

Sudjana. 2005. Teknik Analisis Regresi dan Korelasi bagi Peneliti. Tarsito. Bandung.

Sugiyono. 2014. Metode Penelitian Kuantitatif Kualitatif dan R\&D. Alfabeta. Bandung.

Sunyoto, Danang. 2012. Uji Validitas dan Reliabilitas, Asumsi Klasik untuk Kesehatan. Nuha Medika. Yogyakarta.

Sunyoto, Danang. 2012. Manajemen Sumber Daya Manusia. CAPS. Yogyakarta.

Timpe A. Dale. 2000. Seri Manajemen Sumber Daya Manusia, Produktivitas. Gramedia. Jakarta.

Wibowo. 2013. Manajemen Kinerja. PT. Raja Grafindo Persada. Jakarta.

Widjaja, A.W. 2010. Ilmu Komunikasi Pengantar Studi. PT Rineka Daya Manusia. Jakarta. 